\title{
Preparation of Lignin Carbon/Zinc Oxide Electrode Material and Its Application in Supercapacitors
}

\author{
Gaijuan Guo ${ }^{1,2}$, Zijing Zhou ${ }^{1,2}$, Jinda $\mathrm{Li}^{1,2}$, Hong Yan ${ }^{1,2, *}$ and Fen $\mathrm{Li}^{1,2, *}$ \\ 1 School of Materials Science and Engineering, Harbin University of Science and Technology, \\ Harbin 150040, China; guogaijuan616534@aliyun.com (G.G.); zzj15046043588@aliyun.com (Z.Z.); \\ jinda_li@aliyun.com (J.L.) \\ 2 Key Laboratory of Green Chemical Technology of College of Heilongjiang Province, Harbin 150040, China \\ * Correspondence: yanhong204821@aliyun.com (H.Y.); lifenjiangjiarui@sina.com (F.L.); \\ Tel.: +86-451-863-927-20 (H.Y. \& F.L.); Fax: +86-451-863-927-08 (H.Y. \& F.L.)
}

Citation: Guo, G.; Zhou, Z.; Li, J.; Yan, H.; Li, F. Preparation of Lignin Carbon/Zinc Oxide Electrode Material and Its Application in Supercapacitors. Molecules 2021, 26, 3554. https://doi.org/10.3390/ molecules26123554

Academic Editor: César Augusto Correia de Sequeira

Received: 8 April 2021

Accepted: 4 June 2021

Published: 10 June 2021

Publisher's Note: MDPI stays neutral with regard to jurisdictional claims in published maps and institutional affiliations.

Copyright: (c) 2021 by the authors. Licensee MDPI, Basel, Switzerland. This article is an open access article distributed under the terms and conditions of the Creative Commons Attribution (CC BY) license (https:// creativecommons.org/licenses/by/ $4.0 /)$.

\begin{abstract}
In this paper, carbon/zinc oxide $(\mathrm{LC} / \mathrm{ZnO})$ composites were successfully synthesized and characterized by $\mathrm{X}$-ray powder diffraction, field emission scanning electron microscopy, Fourier transform infrared spectroscopy, Raman, thermogravimetry, and $\mathrm{N}_{2}$ adsorption-desorption, and tested by electrochemical performance. Studies have shown that the morphology of LC/ZnO composites is that lignin pellets are embedded in $\mathrm{ZnO}$ microplates. The lignin carbon in the composites mainly exists in an amorphous structure, and the specific surface area and pore channels of metal oxides are increased by the presence of lignin carbon. The electrochemical performance test shows that the carbonization temperature of $\mathrm{LC} / \mathrm{ZnO}$ with the highest specific capacitance is $550{ }^{\circ} \mathrm{C}$, and the capacitance retention rate reaches $96.74 \%$ after 1000 cycles of testing, indicating that the composite material has good cycle stability. Compared with the control group, it is found that the specific capacitance of $\mathrm{LC} / \mathrm{ZnO}-550{ }^{\circ} \mathrm{C}$ is 2.3 times and 1.8 times that of $\mathrm{ZnO}-550{ }^{\circ} \mathrm{C}$ and $\mathrm{LC}-550{ }^{\circ} \mathrm{C}$, respectively. This shows that during the electrochemical test, the lignin carbon and the metal oxide promote each other and act synergistically. In addition, the composite material exhibits the characteristics of a pseudo-capacitance capacitor, indicating that the redox reaction occurred in the electrochemical performance test.
\end{abstract}

Keywords: lignin carbon; $\mathrm{ZnO}$; composite material; supercapacitors

\section{Introduction}

With the rapid development of the economy, the increasing level of industrialization, and the rapid growth of population, the existing resources developed by humankind have reached an unprecedented level, which has caused various problems such as waste of resources and environmental pollution. These problems threaten the natural environment that humankind depends on for survival and restricts the economic development of all countries in the world. Therefore, the development of clean, energy efficient, and renewable resources has become a hotspot of unanimous research by scientists, and biomass energy has received widespread attention as one of many renewable resources. Among them, lignin is favored by scholars for its advantages of large reserves, a wide range of sources, and environmental protection. As a largely agricultural country, China produces about 50 million tons of industrial lignin (it is the main by-product of papermaking and biorefinery industry) every year [1,2], but more than $95 \%$ of the industrial lignin is not recycled effectively; it is directly discharged into water bodies, causing environmental pollution and waste of resources [3]. Therefore, the high-value application of industrial lignin is of great significance to the recycling of resources, the protection of the environment, and the development of new materials. In addition to biomass energy, wind energy, solar energy, tidal energy, etc. are also well-known renewable energy sources, but the utilization of most of them will be affected by climate, environment, and seasons. High-efficiency energy storage devices are needed to deal with these green energy sources for storage 
and conversion [4]. Supercapacitors (also known as electrochemical capacitors), as a kind of energy storage devices with high power, fast charging and discharging performance, and long cycle life, are widely used in various aspects [5-11] such as hybrid electric vehicles, digital communication equipment, storage backup system, smart power grid, energy development, electronic products, etc.

As one of the electrode materials for supercapacitors, metal oxides will not be used as the electrode material for supercapacitors alone due to their disadvantages such as poor conductivity, short cycle life, and low-rate performance. However, we can use the advantages of porous carbon materials such as good conductivity to compound metal oxides to solve this problem. Therefore, researchers have found that using porous carbon materials to compound metal oxides can effectively improve the electrochemical properties of metal oxides [12]. In recent years, many carbon/metal oxide composites with good properties of supercapacitors have been widely reported, for example, graphene/cobalt tetroxide $\left(\mathrm{GR} / \mathrm{Co}_{3} \mathrm{O}_{4}\right)$ [13], porous carbon/manganese dioxide $\left(\mathrm{PC} / \mathrm{MnO}_{2}\right)$ [14], carbon nanotubes/zinc oxide (CNTs/ZnO) [15], etc. [16-19]. Lignin is a polymer compound with a three-dimensional network structure. Carbonization can form a graphene-like material with a certain pore structure (referred to as lignin carbon), which is an effective substitute for carbon-based materials. If lignin carbon is combined with metal oxides, it can improve the photoelectric properties of metal oxides and provide a favorable way for the resource utilization of industrial lignin. At present, most researchers use plant-based carbon as the electrode material for supercapacitors. For example, $\mathrm{Xu}$ et al. used wheat gluten as a carbon source to prepare a carbon material as a supercapacitor electrode material. According to the test, its specific capacitance can reach $350 \mathrm{~F} / \mathrm{g}$, indicating that the carbon material has excellent electrochemical properties [20]. Sevilla et al. used eucalyptus sawdust as a carbon source to prepare a supercapacitor carbon electrode material, which showed high specific capacitance in different electrolytes [21]. It can be seen that plant-based lignin carbon is a good carbon electrode material for supercapacitors [22-24]. In addition, industrial lignin can also be used as a carbon source to composite with metal oxides to prepare electrode materials for supercapacitors. For example, Li et al. prepared supercapacitor electrode materials by using activated carbon derived from walnut shell and zinc oxide, and the results showed that the specific capacitance of the composite material was $117.4 \mathrm{~F} / \mathrm{g}$, which basically remained stable after 1000 cycle tests [25]. Yun et al. used hardwood lignin as the carbon source to prepare carbon nanofibers and zinc oxide electrode materials with a specific capacitance of $165.0 \mathrm{~F} / \mathrm{g}$ and capacitance retention of $94 \%$ after 3000 cycle tests [26]. Chen et al. used lignosulfonate as a carbon source and compounded it with metal oxide $\mathrm{NiO}$ to prepare $\mathrm{NiO} @ \mathrm{MPC}$ composite material and used it as a supercapacitor electrode material. Studies have shown that the material has a high specific capacitance $(880.2 \mathrm{~F} / \mathrm{g})$, and the capacitance retention rate is $93.7 \%$ after 1000 charge and discharge cycles [27]. Therefore, the combination of lignin carbon and metal oxides can improve the electrochemical properties of single metal oxides. Researchers have tried different lignin carbon sources (such as lignosulfonate, walnut shell, and hardwood lignin), but the preparation of supercapacitor electrode materials using alkali lignin as carbon source and metal oxides is rarely reported. As $\mathrm{ZnO}$ has the advantages of wide temperature range, low cost, easy production, and single oxide form, we plan to use alkali lignin as the carbon source and combine it with $\mathrm{ZnO}$ to prepare electrode materials for supercapacitors in order to use the synergy between lignin carbon and metal oxides to improve the capacitance performance of metal oxides as electrode materials; it also provides an effective way for the high-value utilization of alkali lignin. At the same time, it also provides a theoretical basis for the wider application of lignin carbon/metal oxide composite electrode materials.

\section{Results and Discussion}

\subsection{XRD Characterization Analysis}

Figure 1 shows the XRD patterns of $\mathrm{LC} / \mathrm{ZnO}$ composites at different calcination temperatures. As can be observed from Figure 1, the characteristic diffraction peaks of $\mathrm{ZnO}$ 
at $2 \theta$ of $31.7^{\circ}, 34.4^{\circ}, 36.4^{\circ}, 47.5^{\circ}, 56.7^{\circ}, 62.9^{\circ}, 66.4^{\circ}, 67.9^{\circ}$, and $69.2^{\circ}$ are consistent with those of the standard $\mathrm{ZnO}$ (PDF No. 36-1451) card, indicating that the crystal forms of both the prepared $\mathrm{ZnO}$ and the $\mathrm{ZnO}$ in the composite materials belong to hexagonal wurtzite [28,29]. In addition, no other XRD peaks are found in the XRD pattern of $\mathrm{ZnO}$, indicating that there are no impurities in the prepared $\mathrm{ZnO}$ samples. With the gradual increase in the calcination temperature, the diffraction peaks of the metal oxide in the composite material become sharper, indicating that the increase in the calcination temperature is conducive to the formation of oxide crystals. In addition, with the addition of lignin carbon, although the XRD characteristic diffraction peaks of metal oxides in the composite material have changed, the main peak shape has not changed. It shows that $\mathrm{LC} / \mathrm{ZnO}$ is successfully synthesized, and the addition of lignin carbon does not change the structure of the metal oxide. Moreover, the XRD pattern of the $\mathrm{LC} / \mathrm{ZnO}$ composite material does not show an obvious diffraction peak of lignin carbon, which is because the lignin carbon mainly exists in the composite material in an amorphous structure.

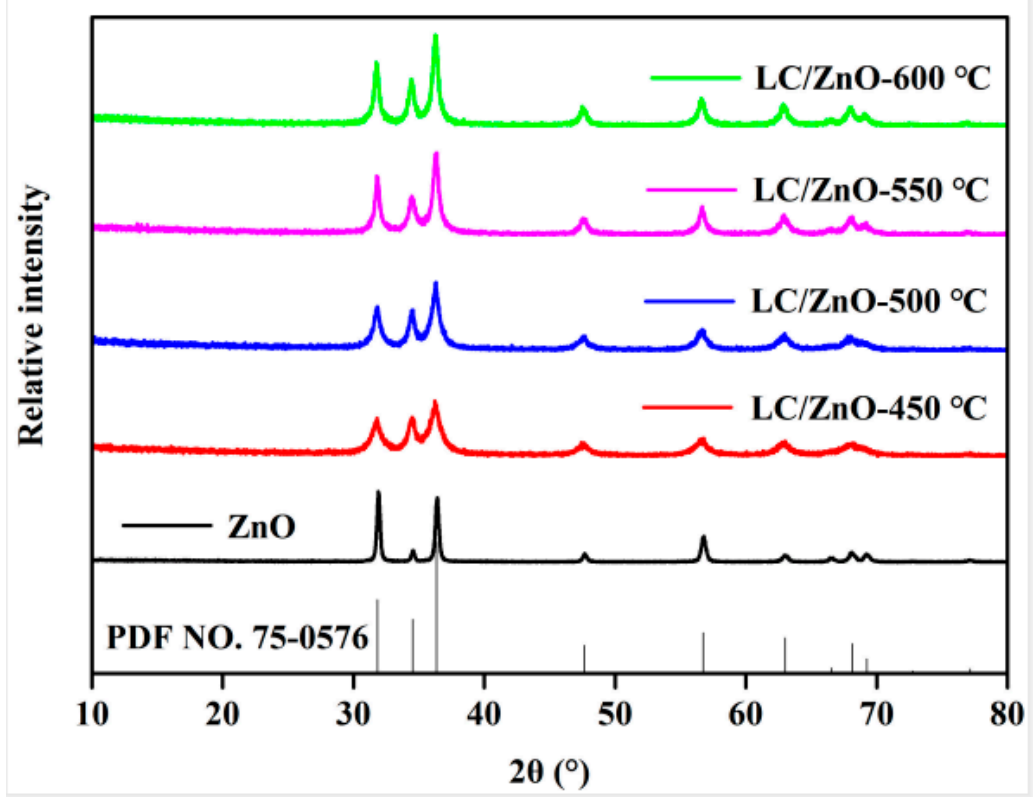

Figure 1. XRD patterns of LC/ZnO composites.

\subsection{FESEM Characterization Analysis}

Figure 2 shows the scanning electron micrographs of $\mathrm{LC} / \mathrm{ZnO}$ at different calcination temperatures, QAL and ZnO. Figure 2a is the SEM image of QAL. It can be seen that QAL is composed of many nanospheres with smooth surfaces. It can be inferred from Figure $2 \mathrm{~b}$ that $\mathrm{ZnO}$ alone is composed of a large number of irregular microplates with holes on the surface. Figure $2 \mathrm{c}-\mathrm{f}$ is the scanning electron micrographs of $\mathrm{LC} / \mathrm{ZnO}$ at different calcination temperatures. It can be observed that with the recombination of lignin, the morphology of $\mathrm{ZnO}$ microplates changes from rectangles with different lengths and widths to elliptical microplates. Additionally, with the increase in the calcination temperature, the $\mathrm{ZnO}$ microplates agglomerate. At $450{ }^{\circ} \mathrm{C}$, the pores on the surface of the $\mathrm{ZnO}$ microplates in $\mathrm{LC} / \mathrm{ZnO}$ disappear, and its surface becomes rough because the lignin nanospheres begin to be embedded in the $\mathrm{ZnO}$ microplates. Additionally, when the carbonization temperature continues to rise to $600{ }^{\circ} \mathrm{C}$, the surface of the $\mathrm{ZnO}$ microplates in the $\mathrm{LC} / \mathrm{ZnO}$ gradually changes from roughness to smoothness. These phenomena prove the successful synthesis of $\mathrm{LC} / \mathrm{ZnO}$. 

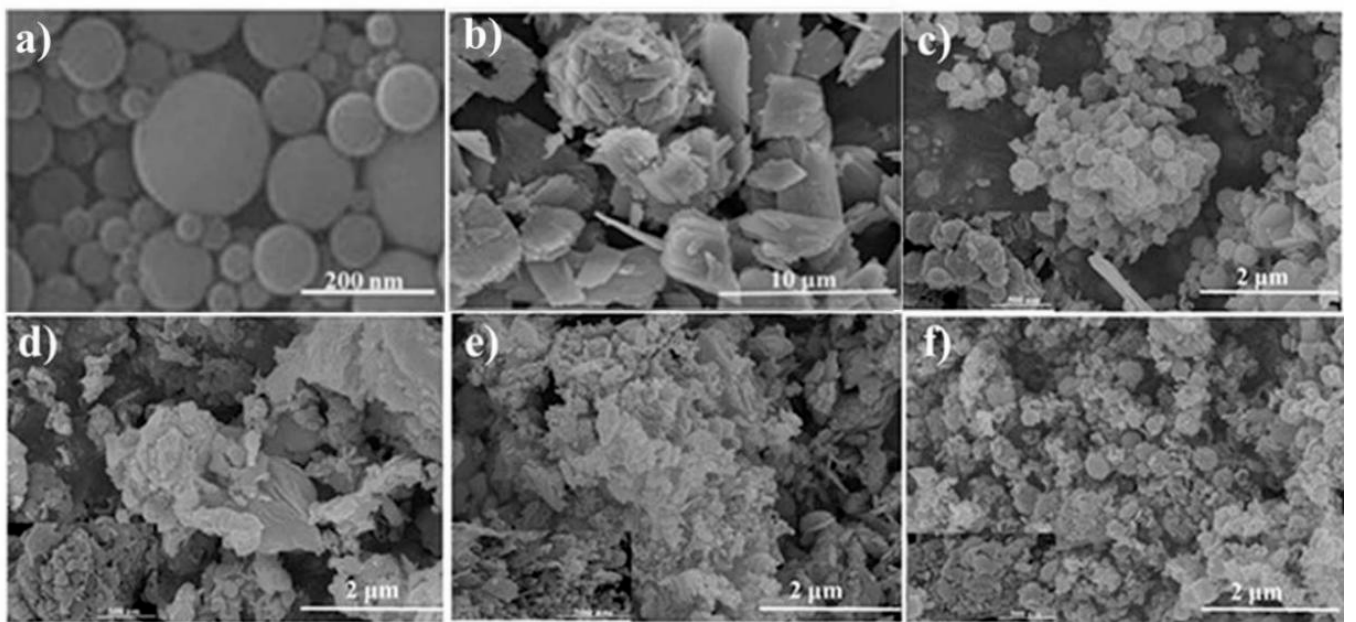

Figure 2. SEM images of $\mathrm{LC} / \mathrm{ZnO}$ (a) QAL; (b) $\mathrm{ZnO}$; (c) $\mathrm{LC} / \mathrm{ZnO}-450{ }^{\circ} \mathrm{C}$ (inset: $\mathrm{SEM}$ image of $500 \mathrm{~nm}$ ); (d) LC $/ \mathrm{ZnO}-500{ }^{\circ} \mathrm{C}$ (inset: SEM image of $500 \mathrm{~nm}$ ); (e) LC/ZnO-550 ${ }^{\circ} \mathrm{C}$ (inset: SEM image of $500 \mathrm{~nm}$ ); (f) $\mathrm{LC} / \mathrm{ZnO}-600{ }^{\circ} \mathrm{C}$ (inset: SEM image of $500 \mathrm{~nm}$ )).

\subsection{FT-IR and Raman Characterization Analysis}

Figure 3 shows the FT-IR and Raman spectra of LC/ZnO at different calcination temperatures. Figure 3 a shows the infrared spectra of $\mathrm{LC} / \mathrm{ZnO}$ at different calcination temperatures. The peak at $1535 \mathrm{~cm}^{-1}$ is the stretching vibration of $\mathrm{C}=\mathrm{O}$ in the aromatic ring [28], the peak at $1466 \mathrm{~cm}^{-1}$ corresponds to the stretching vibration of the $\mathrm{C}-\mathrm{OH}$ bond in the aromatic ring [30], and the peak at $1397 \mathrm{~cm}^{-1}$ corresponds to the stretching vibration of the $\mathrm{C}-\mathrm{H}$ bond in the alkyl group. Comparing the composite material with the uncarbonized QAL, it is found that the peaks of $\mathrm{C}=\mathrm{O}, \mathrm{C}-\mathrm{OH}, \mathrm{C}-\mathrm{H}$, etc. in the lignin disappear, indicating that the lignin is carbonized. In addition, the infrared spectrum of $\mathrm{LC} / \mathrm{ZnO}$ is similar to that of $\mathrm{ZnO}$ alone. $\mathrm{ZnO}$ alone has a characteristic peak of $\mathrm{Zn}-\mathrm{O}$ bond at $491 \mathrm{~cm}^{-1}$, and the peak of $491 \mathrm{~cm}^{-1}$ exits in the infrared spectrum of $\mathrm{LC} / \mathrm{ZnO}$, indicating that $\mathrm{LC} / \mathrm{ZnO}$ has been successfully made. Moreover, with the increase in the calcination temperature of the composite material, the peak of $491 \mathrm{~cm}^{-1}$ in the infrared spectrum of $\mathrm{LC} / \mathrm{ZnO}$ becomes more and more obvious, indicating that increasing the temperature is beneficial to the formation of $\mathrm{Zn}-\mathrm{O}$. Figure $3 \mathrm{~b}$ is the Raman spectra of $\mathrm{LC} / \mathrm{ZnO}$ at different calcination temperatures. It is known that the peak at $1357 \mathrm{~cm}^{-1}$ is the D peak, which indicates the presence of disorder and defects in the carbon structure. Additionally, the peak at $1589 \mathrm{~cm}^{-1}$ is the $\mathrm{G}$ peak, which reflects the presence of disordered sp $\mathrm{p}^{2}$ hybrid carbon in the carbon structure. $\mathrm{I}_{\mathrm{D}} / \mathrm{I}_{\mathrm{G}}$ (intensity ratio) is generally used to estimate the degree of disorder in $\mathrm{sp}^{2}$ hybridized carbon regions [12]. The higher the $\mathrm{I}_{\mathrm{D}} / \mathrm{I}_{\mathrm{G}}$ is, the higher the degree of disorder. According to the Raman spectrum, the $\mathrm{I}_{\mathrm{D}} / \mathrm{I}_{\mathrm{G}}$ of $\mathrm{LC} / \mathrm{ZnO}-450{ }^{\circ} \mathrm{C}, \mathrm{LC} / \mathrm{ZnO}-500$, $\mathrm{LC} / \mathrm{ZnO}-550{ }^{\circ} \mathrm{C}$, and $\mathrm{LC} / \mathrm{ZnO}-600{ }^{\circ} \mathrm{C}$ are $0.765,0.769,0.784$, and 0.786 , respectively. As the temperature increases, $\mathrm{I}_{\mathrm{D}} / \mathrm{I}_{\mathrm{G}}$ also increases, indicating that the $\mathrm{sp}^{2}$ hybrid carbon region becomes more disordered under higher temperature conditions, and more defects are formed, which is not conducive to the study of electrochemical performance. 
a)

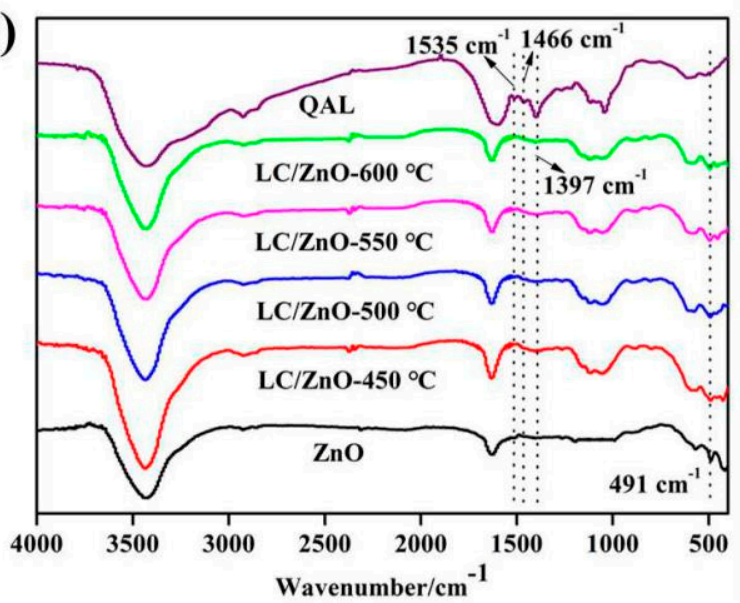

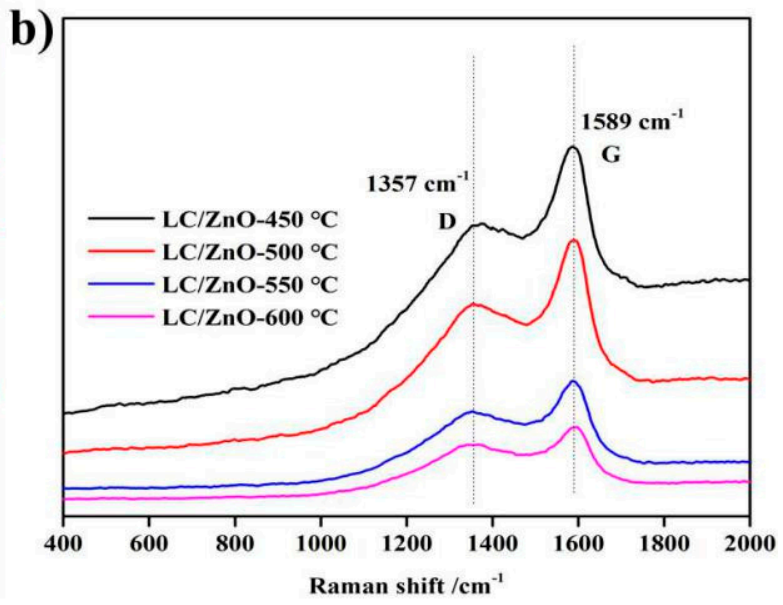

Figure 3. Spectra of LC/ZnO: (a) FT-IR; (b) Raman.

\subsection{TG Characterization Analysis}

Figure 4 shows the TG graphs of $\mathrm{LC} / \mathrm{ZnO}$ at different calcination temperatures. It can be seen from the figure that lignin pyrolysis is basically divided into three stages. The first stage is the removal of free water below $200^{\circ} \mathrm{C}$. The second stage is the significant weight loss caused by the breakage of a large number of functional group branches connecting the phenylpropane structure at $200-500^{\circ} \mathrm{C}$. The third stage is the condensation polymerization and rearrangement of the benzene ring above $500^{\circ} \mathrm{C}$. The carbon content of $\mathrm{LC} / \mathrm{ZnO}$ at different calcination temperatures is $14.3 \%\left(\mathrm{LC} / \mathrm{ZnO}-450{ }^{\circ} \mathrm{C}\right), 12.2 \%\left(\mathrm{LC} / \mathrm{ZnO}-500{ }^{\circ} \mathrm{C}\right)$, $12.0 \%\left(\mathrm{LC} / \mathrm{ZnO}-550{ }^{\circ} \mathrm{C}\right), 9.0 \%\left(\mathrm{LC} / \mathrm{ZnO}-600{ }^{\circ} \mathrm{C}\right)$, respectively. It can be observed that as the calcination temperature increases, the carbon content in the composite material gradually decreases. This is because lignin is easily decomposed at high temperatures. Therefore, the higher the calcination temperature is, the lower the content of the lignin.

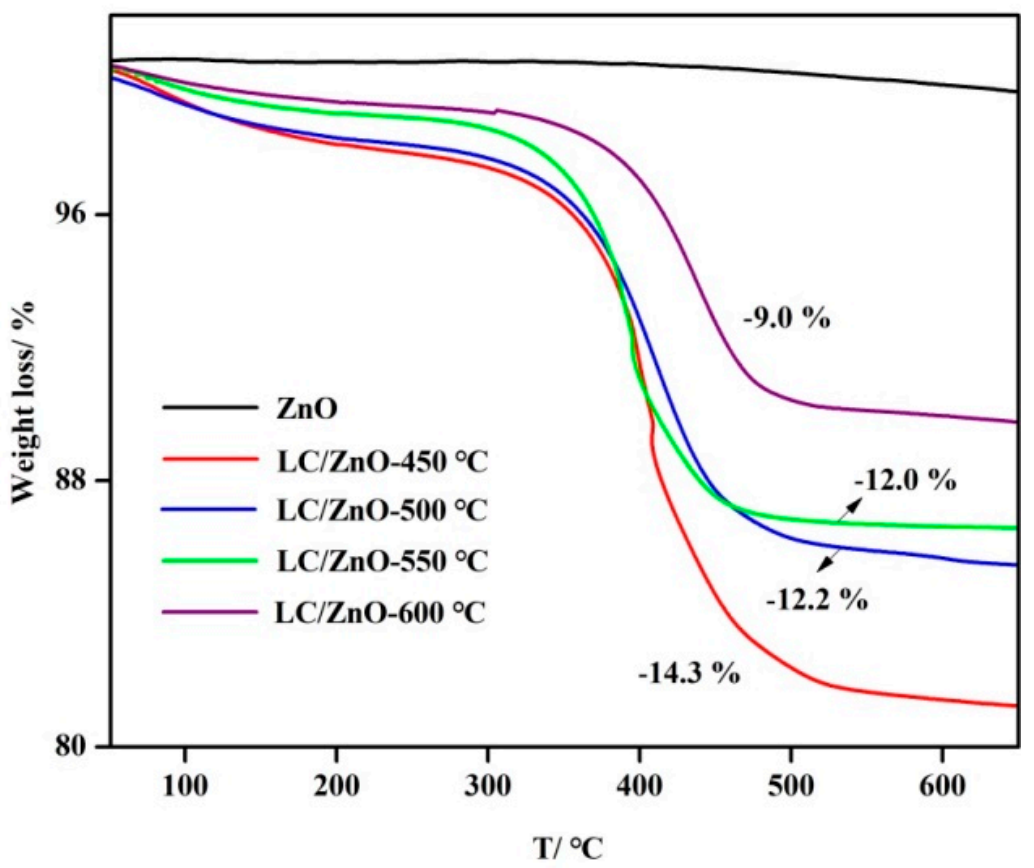

Figure 4. TG image of $\mathrm{LC} / \mathrm{ZnO}$ composite. 


\subsection{Characterization and Analysis of $\mathrm{N}_{2}$ Adsorption-Desorption}

According to the previous characterization analysis and the subsequent electrochemical performance research results, we measured the specific surface area and pore diameter of $\mathrm{LC} / \mathrm{ZnO}-550{ }^{\circ} \mathrm{C}$ and $\mathrm{ZnO}-550{ }^{\circ} \mathrm{C}$, respectively. It can be seen from Figure $5 \mathrm{a}$ that the adsorption isotherm of $\mathrm{LC} / \mathrm{ZnO}-550{ }^{\circ} \mathrm{C}$ conforms to type IV isotherm, and the $\mathrm{H}_{3}$ hysteresis loop appears when $\mathrm{P} / \mathrm{P}_{0}>0.45$, indicating that there are a lot of mesopores in the structure of $\mathrm{LC} / \mathrm{ZnO}-550{ }^{\circ} \mathrm{C}$. The $\mathrm{N}_{2}$ adsorption-desorption isotherm of $\mathrm{ZnO}-550{ }^{\circ} \mathrm{C}$ is a typical I-type isotherm at low pressure, and there is a hysteresis loop at $\mathrm{P} / \mathrm{P}_{0}>0.2$, indicating that there are micropores in the $\mathrm{ZnO}$ structure. A typical IV-type isotherm is observed at medium pressure, and there is an $\mathrm{H}_{3}$ hysteresis loop at $\mathrm{P} / \mathrm{P}_{0}>0.75$, indicating that mesopores exist in the $\mathrm{ZnO}$ structure. Secondly, under high-pressure conditions, $\mathrm{LC} / \mathrm{ZnO}$ $550{ }^{\circ} \mathrm{C}$ has a larger adsorption capacity than $\mathrm{ZnO}-550{ }^{\circ} \mathrm{C}$, indicating that the structure of $\mathrm{LC} / \mathrm{ZnO}-550^{\circ} \mathrm{C}$ contains more abundant pores [31]. According to Figure $5 b$, the pore structure type of $\mathrm{ZnO}-550^{\circ} \mathrm{C}$ may be composed of micropores, mesopores, and macropores, while the pore structure type of $\mathrm{LC} / \mathrm{ZnO}-550{ }^{\circ} \mathrm{C}$ may be composed of mesopores and macropores. The change in the structure of the hole can be proved from the scanning electron microscope (Figure $2 \mathrm{~b}, \mathrm{e})$. In addition, the specific surface area $\left(157.60 \mathrm{~m}^{2} / \mathrm{g}\right)$ of $\mathrm{LC} / \mathrm{ZnO}-550{ }^{\circ} \mathrm{C}$ is 23.2 times that of $\mathrm{ZnO}-550{ }^{\circ} \mathrm{C}\left(6.79 \mathrm{~m}^{2} / \mathrm{g}\right)$. Additionally, according to the analysis of scanning electron microscope (Figure $2 \mathrm{~b}, \mathrm{e}$ ), $\mathrm{LC} / \mathrm{ZnO}-550{ }^{\circ} \mathrm{C}$ increases the specific surface area by expanding the pore volume, and this can also be achieved by $\mathrm{LC} / \mathrm{ZnO}-550{ }^{\circ} \mathrm{C}\left(0.21 \mathrm{~m}^{3} / \mathrm{g}\right)$ and $\mathrm{ZnO}-550{ }^{\circ} \mathrm{C}\left(0.02 \mathrm{~m}^{3} / \mathrm{g}\right)$ pore volume size.
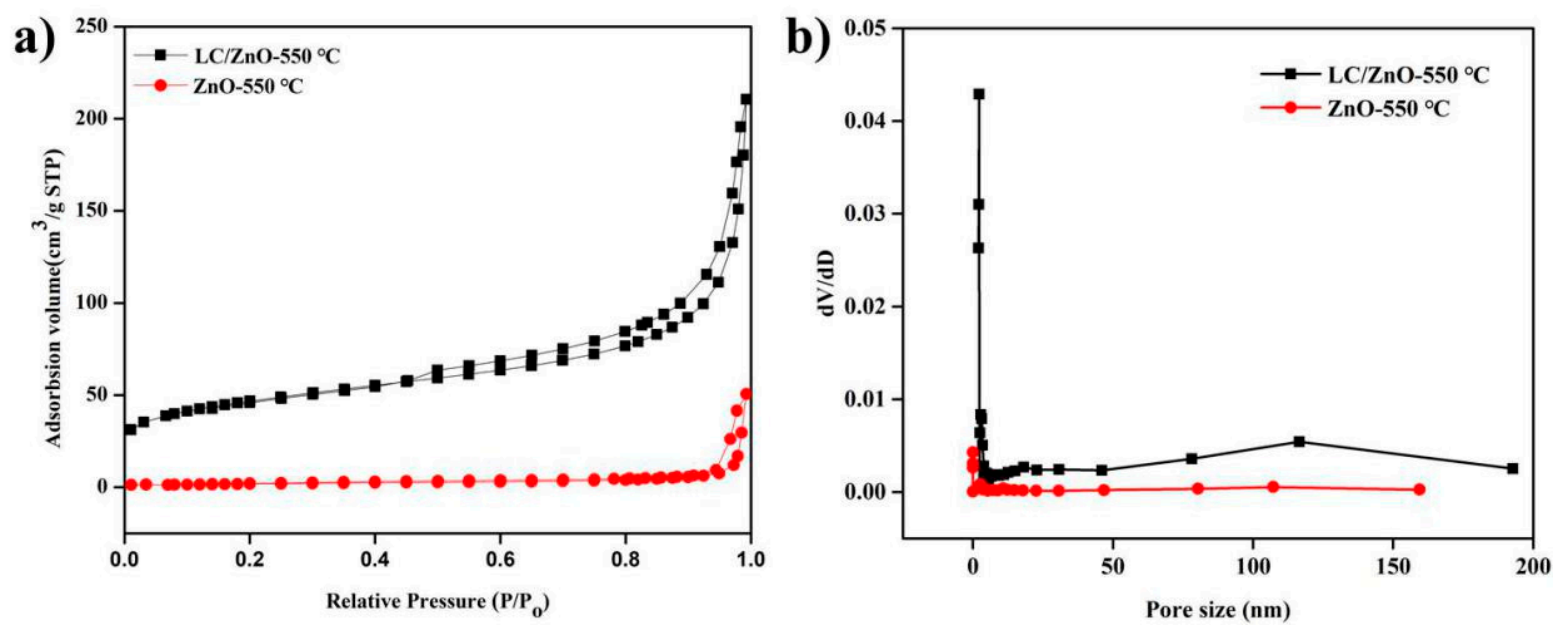

Figure 5. Nitrogen adsorption and desorption isotherms and pore size distribution of $\mathrm{LC} / \mathrm{ZnO}-550{ }^{\circ} \mathrm{C}$ and $\mathrm{ZnO}-550{ }^{\circ} \mathrm{C}$ : (a) nitrogen adsorption and desorption isotherms; (b) pore size distribution.

\subsection{Cyclic Voltammetry}

Figure 6a shows the $\mathrm{CV}$ curves of $\mathrm{LC} / \mathrm{ZnO}$ at different calcination temperatures and $\mathrm{ZnO}$ alone in a three-electrode system at a sweep rate of $0.1 \mathrm{~V} / \mathrm{s}$. It can be seen from the figure that the $\mathrm{CV}$ curves of $\mathrm{LC} / \mathrm{ZnO}$ all show obvious redox peaks. This feature is the characteristic of pseudo-capacitance capacitors, indicating that the capacitors formed by $\mathrm{LC} / \mathrm{ZnO}$ are all pseudo-capacitance capacitors. The upwardly protruding peak is an oxidation peak, indicating that an oxidation reaction (oxygen evolution reaction) has occurred. The downwardly protruding peak is a reduction peak, indicating that a reduction reaction (hydrogen evolution reaction) has occurred. In addition, the area that is enclosed by the $\mathrm{CV}$ curve can be regarded as the specific capacitance of composite material. It can be seen from Figure $6 \mathrm{a}$ that the area enclosed by the $\mathrm{CV}$ curve of $\mathrm{LC} / \mathrm{ZnO}-550{ }^{\circ} \mathrm{C}$ is the largest; therefore, it has the highest specific capacitance, and its specific capacitance is larger than that of $\mathrm{ZnO}-550{ }^{\circ} \mathrm{C}$, indicating that the presence of lignin carbon greatly improves the electrochemical performance of metal oxides. Figure $6 \mathrm{~b}$ shows the CV 
curve of $\mathrm{LC} / \mathrm{ZnO}-550{ }^{\circ} \mathrm{C}$ tested at different scanning speeds. It can be observed from Figure $6 \mathrm{~b}$ that the larger the scanning speed is, the larger the area covered by the CV curve, indicating that increasing the scanning speed can increase the specific capacitance of the composite material. Additionally, when the scanning speed is increased to $0.2 \mathrm{~V} / \mathrm{s}$, the curve still maintains the original redox peak, indicating that $\mathrm{LC} / \mathrm{ZnO}-550{ }^{\circ} \mathrm{C}$ has a good rate performance.
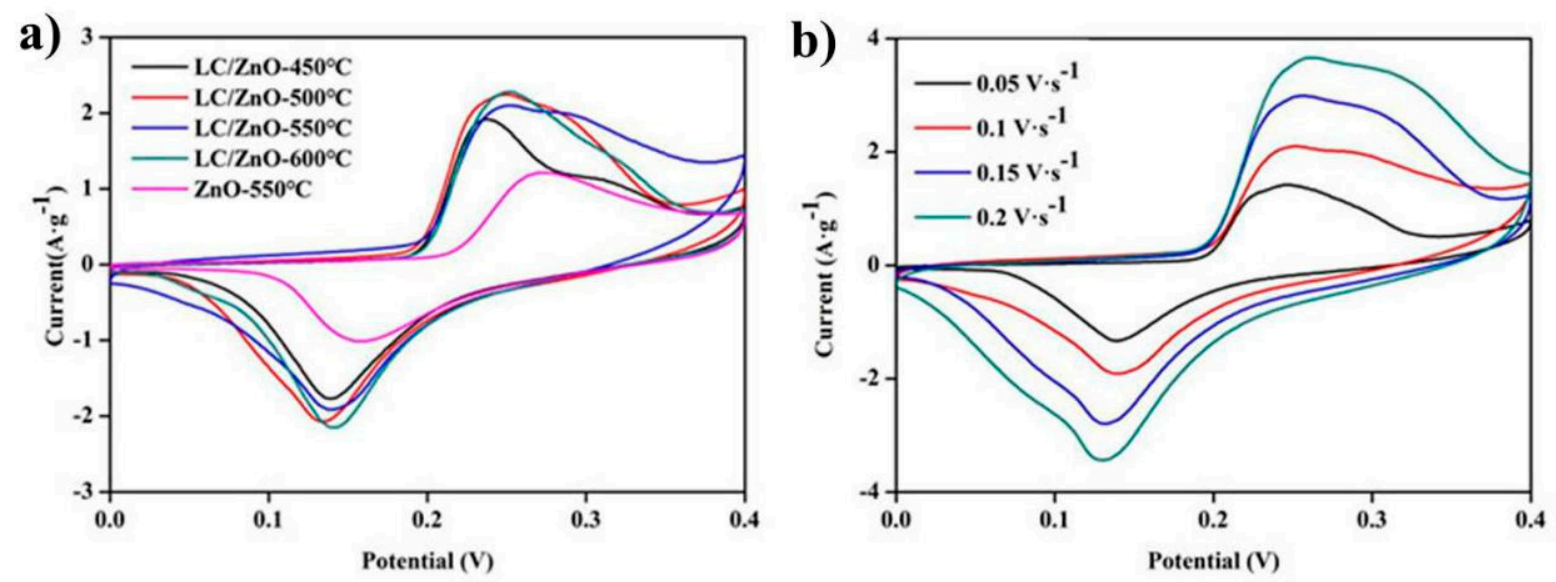

Figure 6. (a) $\mathrm{CV}$ curves of $\mathrm{LC} / \mathrm{ZnO}$ at scan rates of $0.1 \mathrm{~V} \cdot \mathrm{s}^{-1}$; (b) $\mathrm{CV}$ curves of $\mathrm{LC} / \mathrm{ZnO}-550{ }^{\circ} \mathrm{C}$ at different scan rates.

\subsection{Galvanostatic Charge/Discharge}

Figure 7 shows the GCD curves of $\mathrm{LC} / \mathrm{ZnO}$ at different calcination temperatures, $\mathrm{ZnO}$ and $\mathrm{LC}$ at $0.1 \mathrm{~A} / \mathrm{g}$. It can be seen that the GCD curve of $\mathrm{LC} / \mathrm{ZnO}$ at each temperature shows a clear charge and discharge platform, indicating that a significant oxidation-reduction reaction occurred during the charge and discharge process. This result is consistent with the analysis result of cyclic voltammetry. According to Formula (5), the weight-specific capacitances of $\mathrm{LC} / \mathrm{ZnO}-450{ }^{\circ} \mathrm{C}, \mathrm{LC} / \mathrm{ZnO}-500{ }^{\circ} \mathrm{C}, \mathrm{LC} / \mathrm{ZnO}-550{ }^{\circ} \mathrm{C}$, and $\mathrm{LC} / \mathrm{ZnO}-600$ ${ }^{\circ} \mathrm{C}$ are calculated as $65 \mathrm{~F} / \mathrm{kg}, 81 \mathrm{~F} / \mathrm{kg}, 101 \mathrm{~F} / \mathrm{kg}$, and $92 \mathrm{~F} / \mathrm{kg}$, respectively. It can be inferred that the weight-specific capacitance of the composite material shows a trend of first increasing and then decreasing as the temperature rises, and the weight-specific capacitance of $\mathrm{LC} / \mathrm{ZnO}$ reaches the highest at $550^{\circ} \mathrm{C}$. According to Formulas (6) and (7), the energy density and power density of the composite materials are shown in Table 1 . The energy densities of $\mathrm{LC} / \mathrm{ZnO}-450{ }^{\circ} \mathrm{C}, \mathrm{LC} / \mathrm{ZnO}-500{ }^{\circ} \mathrm{C}, \mathrm{LC} / \mathrm{ZnO}-550{ }^{\circ} \mathrm{C}$, and $\mathrm{LC} / \mathrm{ZnO}-600{ }^{\circ} \mathrm{C}$ are calculated as $3.98 \mathrm{~W} \cdot \mathrm{s} / \mathrm{kg}, 4.96 \mathrm{~W} \cdot \mathrm{s} / \mathrm{kg}, 6.19 \mathrm{~W} \cdot \mathrm{s} / \mathrm{kg}$, and $5.64 \mathrm{~W} \cdot \mathrm{s} / \mathrm{kg}$, and the power density is $0.173 \mathrm{~W} / \mathrm{kg}, 0.177 \mathrm{~W} / \mathrm{kg}, 0.177 \mathrm{~W} / \mathrm{kg}$ and $0.176 \mathrm{~W} / \mathrm{kg}$, respectively. In addition, the weight-specific capacitance of $\mathrm{LC} / \mathrm{ZnO}-550{ }^{\circ} \mathrm{C}$ is 2.3 times that of $\mathrm{ZnO}-550{ }^{\circ} \mathrm{C}(43 \mathrm{~F} / \mathrm{kg})$ and 1.8 times that of $\mathrm{LC}-550{ }^{\circ} \mathrm{C}(57 \mathrm{~F} / \mathrm{kg})$. It can be inferred that the combination of lignin carbon and metal oxide can effectively improve the electrochemical performance of each other. This is because they both synergize and promote each other. The metal oxide protects the lignin from being decomposed, and lignin increases the specific surface area and pores of metal oxides.

\subsection{Electrochemical Impedance Spectroscopy}

Figure 8 shows the electrochemical impedance spectroscopy of $\mathrm{LC} / \mathrm{ZnO}$ at different calcination temperatures. It can be observed from Figure 8 that the $\mathrm{LC} / \mathrm{ZnO}$ at different calcination temperatures all appear to be semicircular in the high-frequency region, and there is a nearly $90^{\circ}$ straight line in the low-frequency region, indicating that $\mathrm{LC} / \mathrm{ZnO}$ with different calcination temperature all show good capacitance performance. In the high-frequency region, the charge transfer resistance (Rct) of the interface between the $\mathrm{LC} / \mathrm{ZnO}$ electrode material and the electrolyte can be estimated based on the diameter of the semicircle in the Nyquist diagram. This resistance comes from the electron transfer process on the electrode surface [30]. According to the fitted equivalent circuit, the charge 
transfer resistance contained in the $\mathrm{LC} / \mathrm{ZnO}$ at each calcination temperature is about $1.28 \Omega\left(\mathrm{LC} / \mathrm{ZnO}-450{ }^{\circ} \mathrm{C}\right), 1.10 \Omega\left(\mathrm{LC} / \mathrm{ZnO}-500{ }^{\circ} \mathrm{C}\right), 0.47 \Omega\left(\mathrm{LC} / \mathrm{ZnO}-550{ }^{\circ} \mathrm{C}\right)$, and $0.58 \Omega$ $\left(\mathrm{LC} / \mathrm{ZnO}-600^{\circ} \mathrm{C}\right)$. At the same time, the steepness of the linear curve in the low-frequency region indicates the size of the diffusion resistance. The steeper the curve is, the smaller the diffusion resistance, the flatter the curve, and the greater the diffusion resistance. Therefore, $\mathrm{LC} / \mathrm{ZnO}$ with different calcination temperatures basically exhibits a typical capacitance behavior with low diffusion resistance [32]. In addition, in the high-frequency region, the intercept of the Nernst curve and the abscissa represents the equivalent series resistance (ESR) of the composite material. ESR is composed of the resistance of the electrolyte and the contact resistance and the inherent resistance of the composite material and the nickel foam [30]. The equivalent series resistance of $\mathrm{LC} / \mathrm{ZnO}$ in supercapacitors are $0.16 \Omega\left(\mathrm{LC} / \mathrm{ZnO}-450{ }^{\circ} \mathrm{C}\right), 0.13 \Omega\left(\mathrm{LC} / \mathrm{ZnO}-500{ }^{\circ} \mathrm{C}\right), 0.09 \Omega\left(\mathrm{LC} / \mathrm{ZnO}-500{ }^{\circ} \mathrm{C}\right)$, and $0.11 \Omega\left(\mathrm{LC} / \mathrm{ZnO}-600{ }^{\circ} \mathrm{C}\right)$, respectively. It can be seen that the resistance of $\mathrm{LC} / \mathrm{ZnO}$ supercapacitors at different temperatures shows a trend that first decreases and then rises as the temperature rises, and the resistance of $\mathrm{LC} / \mathrm{ZnO}$ supercapacitors reaches the lowest at $550{ }^{\circ} \mathrm{C}$. In summary, the supercapacitor based on LC/ZnO- $550{ }^{\circ} \mathrm{C}$ has the lowest resistance; therefore, it is considered that it has the best electrochemical performance.

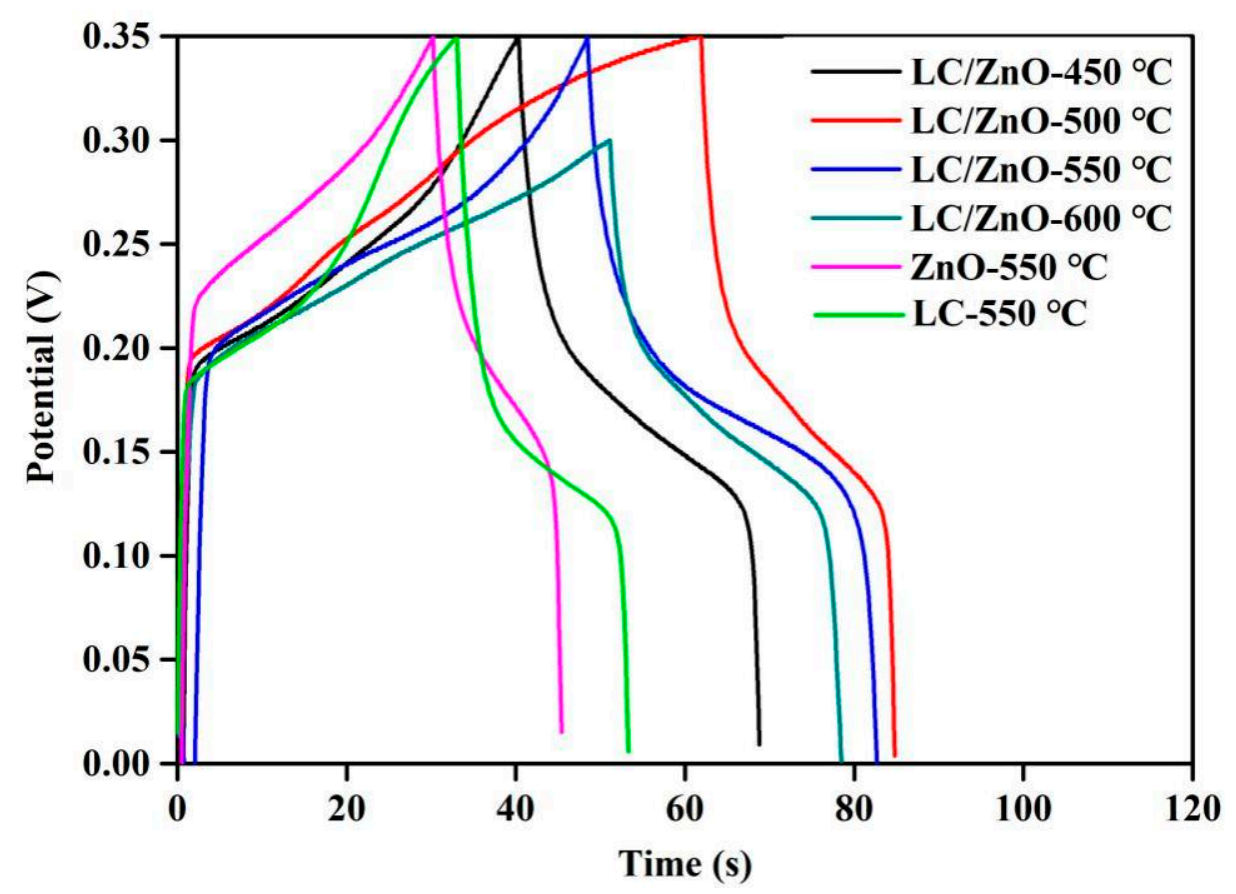

Figure 7. GCD curves at $0.1 \mathrm{~A} / \mathrm{g}$ of the $\mathrm{LC} / \mathrm{ZnO}$ composites.

Table 1. Energy density and power density of $\mathrm{LC} / \mathrm{ZnO}$ composites.

\begin{tabular}{ccccc}
\hline Composites & $\mathrm{LC} / \mathrm{ZnO}-450{ }^{\circ} \mathrm{C}$ & $\mathrm{LC} / \mathrm{ZnO}-500{ }^{\circ} \mathrm{C}$ & $\mathrm{LC} / \mathrm{ZnO}-550{ }^{\circ} \mathrm{C}$ & $\mathrm{LC} / \mathrm{ZnO}-600{ }^{\circ} \mathrm{C}$ \\
\hline $\begin{array}{c}\text { Energy density } \\
(\mathrm{W} \cdot \mathrm{s} / \mathrm{kg})\end{array}$ & 3.98 & 4.96 & 6.19 & 5.64 \\
$\begin{array}{c}\text { Power density } \\
(\mathrm{W} / \mathrm{kg})\end{array}$ & 0.173 & 0.177 & 0.177 & 0.176 \\
\hline
\end{tabular}




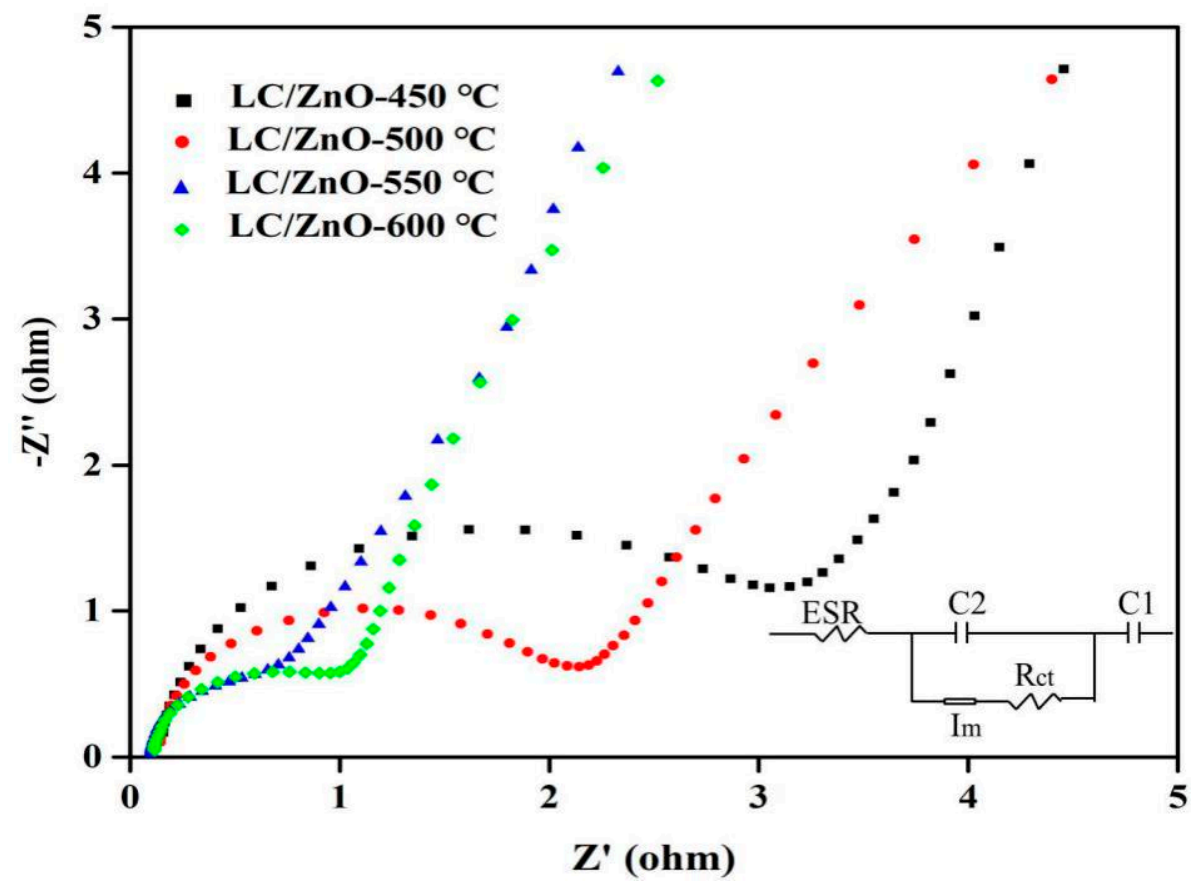

Figure 8. Nyquist plot and fitted equivalent circuit diagrams (inset) of LC/ZnO composites at different temperatures ( $\mathrm{C} 1$ refers to the external power supply. $\mathrm{C} 2$ refers to the three-electrode system. Rct refers to the charge transfer resistance of the interface between the LC/ ZnO electrode material and the electrolyte. ESR refers to the the equivalent series resistance of the composite material. Im is equivalent to a galvanometer).

\subsection{Cycle Performance Test}

In this thesis, the $\mathrm{GCD}$ of the $\mathrm{LC} / \mathrm{ZnO}-550{ }^{\circ} \mathrm{C}$ was carried out several times under the current density of $1 \mathrm{~A} / \mathrm{g}$ to study its cycle performance. Figure 9 shows the GCD curve of $\mathrm{LC} / \mathrm{ZnO}-550{ }^{\circ} \mathrm{C}$ at the 1 st and 1000 cycles. It can be seen that after 1000 times of charging and discharging, the capacitance retention rate reached $96.74 \%$. In addition, after 1000 cycles, the GCD curve of $\mathrm{LC} / \mathrm{ZnO}-550{ }^{\circ} \mathrm{C}$ maintains the same shape as the first time, indicating that $\mathrm{LC} / \mathrm{ZnO}-550{ }^{\circ} \mathrm{C}$ has good cycle stability.

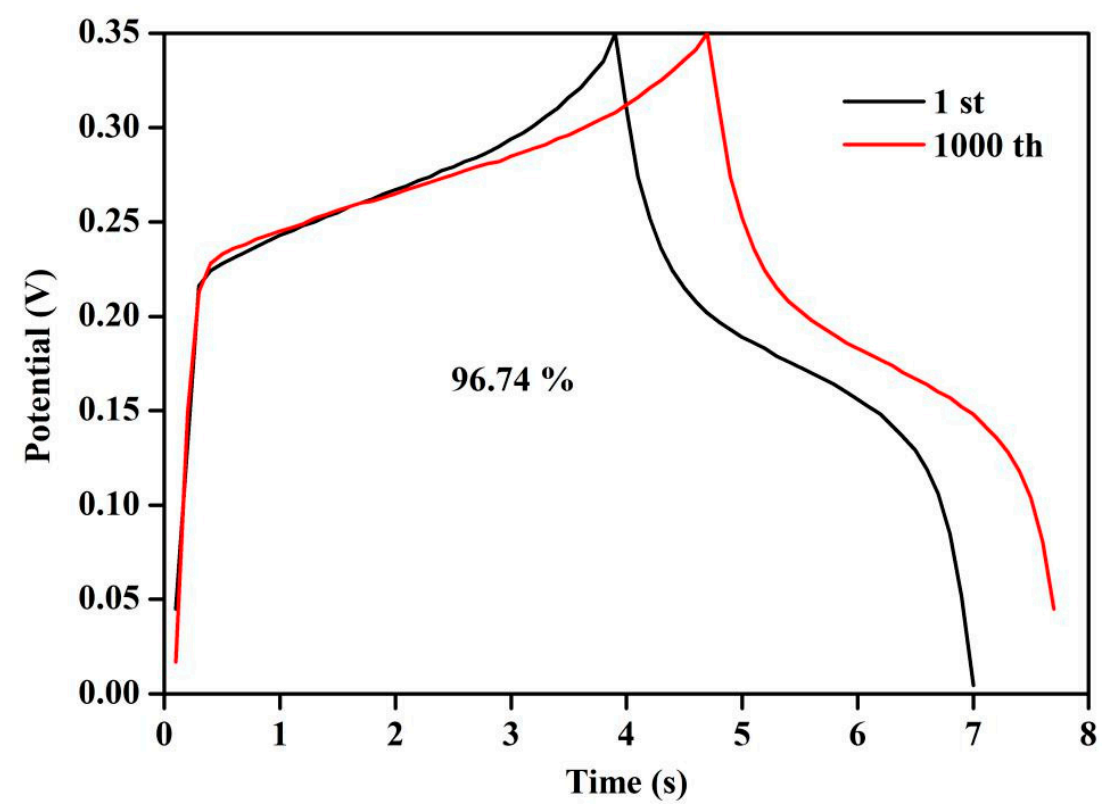

Figure 9. GCD curves at 1 st and 1000 th cycles of $\mathrm{LC} / \mathrm{ZnO}-550{ }^{\circ} \mathrm{C}$ composite. 


\subsection{Mechanism Analysis of Electrochemical Performance}

In the three-electrode system, when there is no external power supply, the positive and negative ions in the $\mathrm{KOH}$ solution present a disordered state. When there is an external power source, electrons flow from the positive electrode to the negative electrode (composite material). The $\mathrm{K}^{+}$moves to the negative electrode, and $\mathrm{OH}^{-}$msoves to the positive electrode due to the electrostatic effect in the $\mathrm{KOH}$ solution. As the composite material has a large specific surface area and abundant pores, electrons can be accumulated on the surface and the pores, and hydrogen evolution occurs. The hydrogen evolution chemical reaction equation of $\mathrm{LC} / \mathrm{ZnO}$ is shown in the following Formula (2). The oxygen evolution reaction occurs on the surface of the positive electrode, and the chemical reaction equation is shown in the following Formula (1). In this case, a large amount of $\mathrm{K}^{+}$in the $\mathrm{KOH}$ solution moves to the negative electrode, and a large amount of $\mathrm{OH}^{-}$moves to the positive electrode; hence, energy is stored. This process is a charging process. The discharging process is the reverse process of the charging process. In this process, the composite material itself acts as a negative electrode, and it will lose the electrons accumulated on its surface and in the pores during the charging process, and an oxygen evolution reaction will occur. The oxidation reaction of $\mathrm{LC} / \mathrm{ZnO}$ is shown in the following Formula (3). At this time, the $\mathrm{OH}^{-}$in the $\mathrm{KOH}$ solution moves to the $\mathrm{LC} / \mathrm{ZnO}$ electrode material. The platinum wire electrode is used as the positive electrode, the electrons losing the $\mathrm{LC} / \mathrm{ZnO}$ electrode material will be obtained and the hydrogen evolution reaction will occur, as shown in the following Formula (4). Additionally, the $\mathrm{K}^{+}$in the $\mathrm{KOH}$ solution moves to the platinum wire electrode; hence, energy is released.

The charging process of $\mathrm{LC} / \mathrm{ZnO}$ is as follows:

$$
\begin{gathered}
4 \mathrm{OH}^{-} \rightarrow \mathrm{O}_{2}+4 \mathrm{e}^{-}+2 \mathrm{H}_{2} \mathrm{O} \\
4 \mathrm{H}_{2} \mathrm{O}+4 e^{-} \rightarrow 2 \mathrm{H}_{2}+4 \mathrm{OH}^{-}
\end{gathered}
$$

The discharge process of $\mathrm{LC} / \mathrm{ZnO}$ is as follows:

$$
\begin{aligned}
& 4 \mathrm{OH}^{-} \rightarrow \mathrm{O}_{2}+4 e^{-}+2 \mathrm{H}_{2} \mathrm{O} \\
& 2 \mathrm{H}_{2} \mathrm{O}+2 e^{-} \rightarrow \mathrm{H}_{2}+2 \mathrm{OH}^{-}
\end{aligned}
$$

\section{Materials and Methods}

\subsection{Preparation Method of Composite Material}

\subsubsection{Activation of Alkali Lignin}

As shown in Figure 10, $9.02 \mathrm{~g}$ of alkali lignin was dissolved in $20 \% \mathrm{NaOH}$ solution, stirred for $30 \mathrm{~min}$, and heated to $85^{\circ} \mathrm{C}$; then, $7.51 \mathrm{~g}$ of trimethylammonium chloride was added drop by drop, kept at $85^{\circ} \mathrm{C}$ for $4 \mathrm{~h}$, and then cooled to room temperature. The cooling product was transferred to a dialysis bag for dialysis to neutral. After that, the dialysis product was concentrated at $80^{\circ} \mathrm{C}$ to viscous and dried at $80^{\circ} \mathrm{C}$ for $24 \mathrm{~h}$ to obtain the activated product of alkali lignin, which was denoted as QAL.

\subsubsection{Preparation of Lignin Carbon/Zinc Oxide Composite Material}

As shown in Figure 11, $0.297 \mathrm{~g} \mathrm{Zn}\left(\mathrm{NO}_{3}\right)_{2} \cdot 6 \mathrm{H}_{2} \mathrm{O}$ was dissolved in $20 \mathrm{~mL}$ ethylene glycol and $5 \mathrm{~mL}$ deionized water and stirred for $30 \mathrm{~min}$; then, $0.6 \mathrm{~g}$ urea was added and continued stirring for $30 \mathrm{~min}$, after which QAL solution (take $0.1 \mathrm{~g}$ QAL dissolved in $10 \mathrm{~mL}$ deionized water) was added drop by drop, stirred for another $30 \mathrm{~min}$, and then the reaction system was transferred to a polytetrafluoroethylene stainless steel reactor, reacted at $120^{\circ} \mathrm{C}$ for $12 \mathrm{~h}$, and cooled to room temperature. It was washed 3 times with deionized water and absolute ethanol and dried at $80{ }^{\circ} \mathrm{C}$ for $12 \mathrm{~h}$ to obtain the product precursor. The product precursor was calcined at a certain temperature $\left(\mathrm{N}_{2}\right.$ atmosphere) to obtain lignin carbon/zinc oxide, which is recorded as $\mathrm{LC} / \mathrm{ZnO}$. 

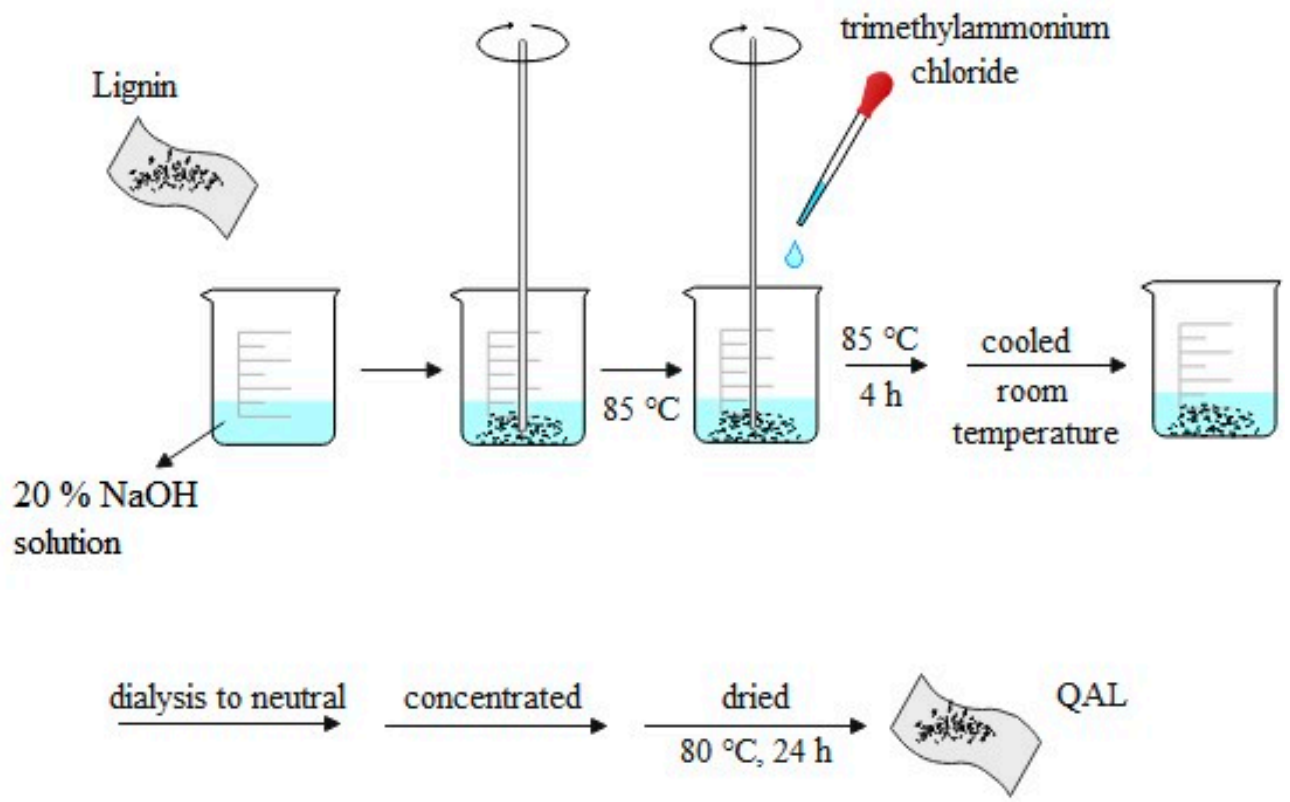

Figure 10. Activation of alkali lignin.

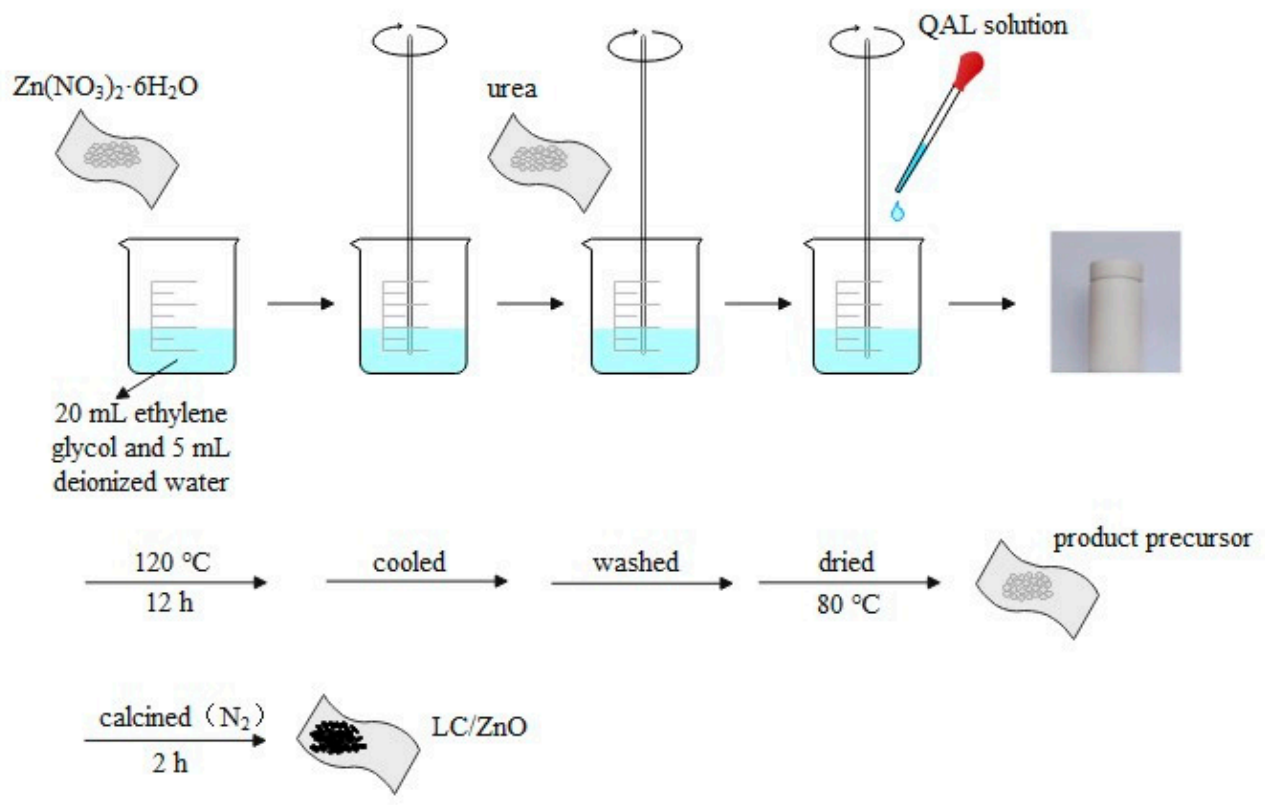

Figure 11. Preparation of $\mathrm{LC} / \mathrm{ZnO}$ composite material.

\subsection{Characterization of Composite Materials}

X-ray powder diffraction (XRD) was used to test the crystalline form of the composite material. The surface morphology of the composite material was observed by field emission scanning electron microscopy (FESEM). The group and carbon structure of composite materials was tested through Fourier transform infrared spectroscopy (FT-IR) and Raman Spectroscopy (Raman). The carbon content of composite materials was determined by thermogravimetry (TG, temperature range $25-700{ }^{\circ} \mathrm{C}$, heating rate: $20^{\circ} \mathrm{C} / \mathrm{min}$, protective gas: $\mathrm{N}_{2}(99.99 \%)$ ). The specific surface area and pore structure of composite materials was determined through $\mathrm{N}_{2}$ adsorption-desorption. 


\subsection{Electrochemical Performance Test}

\subsubsection{Production of Electrode Materials}

The composite material ( $\mathrm{LC} / \mathrm{ZnO}, 0.08 \mathrm{~g}$ ), polytetrafluoroethylene (as adhesive), and conductive carbon black (as conductive agent) with a mass ratio of 80:10:10 were dispersed into $50 \mathrm{~mL}$ anhydrous ethanol, stirred for $30 \mathrm{~min}$, and heated at $80^{\circ} \mathrm{C}$ for $30 \mathrm{~min}$; the elastic solid shaped like plastic clay was rolled onto the foamed nickel and then dried at $80^{\circ} \mathrm{C}$ for $12 \mathrm{~h}$; it was used as the working electrode for standby.

\subsubsection{Cyclic Voltammetry Curve Test}

The saturated calomel electrode was used as the reference electrode, and the platinum electrode was used as the counter electrode. A three-electrode system was formed with the working electrode, the reference electrode, and the counter electrode. The electrochemical performance was tested in a $6 \mathrm{~mol} / \mathrm{L}$ sodium hydroxide solution at room temperature.

Cyclic voltammetry $(\mathrm{CV})$ was used to test the cyclic voltammetry curve of the composite material. The scanning speed of $\mathrm{LC} / \mathrm{ZnO}$ was $0.05 \mathrm{~V} / \mathrm{s}, 0.1 \mathrm{~V} / \mathrm{s}, 0.15 \mathrm{~V} / \mathrm{s}$, and $0.2 \mathrm{~V} / \mathrm{s}$, and the voltage range was $0 \sim 0.4 \mathrm{~V}$.

\subsubsection{Determination of Specific Capacitance}

The composite material was tested by the galvanostatic charge/discharge (GCD) method at a current density of $0.1 \mathrm{~A} / \mathrm{g}$, and the voltage range of $\mathrm{LC} / \mathrm{ZnO}$ was $0 \sim 0.35 \mathrm{~V}$. The following formulas are used to calculate the weight-specific capacitance $(C, F / \mathrm{kg})$, energy density $(E, \mathrm{~W} \cdot \mathrm{s} / \mathrm{kg})$, and power density $(P, \mathrm{~W} / \mathrm{kg})$ of the composite material.

$$
\begin{gathered}
C=\frac{I \Delta t}{m \Delta V} \\
E=\frac{C V^{2}}{2} \\
P=\frac{E}{\Delta \mathrm{t}}
\end{gathered}
$$

where $I$ is the discharge current; $\Delta t$ is the discharge time; $m$ is the mass of the active material; $\Delta V$ is the potential drop during the discharge.

\subsubsection{Simulation of Equivalent Circuit and Determination of Dynamic Parameters}

The equivalent circuit of the electrode system is inferred through the electrochemical impedance spectroscopy (EIS) test, the action mechanism of the composite material in the electrode system is studied, and the kinetic parameters are estimated. The testing method consisted of determining the value of the open-circuit voltage of each composite material and then using the open-circuit voltage to perform an AC impedance test on the composite material.

\section{Conclusions}

In this paper, $\mathrm{ZnO}$ and lignin carbon are used to prepare composite materials $(\mathrm{LC} / \mathrm{ZnO})$, and their characterization and electrochemical performance test are carried out. The results show that the $\mathrm{LC} / \mathrm{ZnO}$ composite material is lignin pellets embedded in $\mathrm{ZnO}$ microplates. The lignin carbon in the composite mainly exists in an amorphous structure, and the presence of lignin carbon increases the specific surface area and pores of the metal oxide. The composite material undergoes an oxidation-reduction reaction in the electrochemical performance test. $\mathrm{LC} / \mathrm{ZnO}$ has the highest weight-specific capacitance at $450{ }^{\circ} \mathrm{C}$, and the specific capacitance of $\mathrm{LC} / \mathrm{ZnO}-550{ }^{\circ} \mathrm{C}$ is 2.3 times and 1.8 times that of $\mathrm{ZnO}-550{ }^{\circ} \mathrm{C}$ and LC- $550{ }^{\circ} \mathrm{C}$, respectively. It can be inferred that lignin carbon and metal oxide synergize and promote each other during the recombination process. At the same time, after 1000 cycles test of $\mathrm{LC} / \mathrm{ZnO}-550{ }^{\circ} \mathrm{C}$, the capacitance retention rate reached $96.74 \%$. It shows that 
the composite material $\left(\mathrm{LC} / \mathrm{ZnO}-550{ }^{\circ} \mathrm{C}\right)$ has the characteristics of a pseudocapacitance capacitor and good cycle stability.

Author Contributions: Conceptualization, H.Y. and G.G., methodology, G.G., software, J.L., validation, G.G. and Z.Z., investigation, G.G., writing—original draft preparation, G.G., writing-review and editing, H.Y., supervision, H.Y. and F.L., funding acquisition, H.Y. All authors have read and agreed to the published version of the manuscript.

Funding: This work was supported by the National Natural Science Foundation of China(21776054).

Data Availability Statement: The data presented in this study are available within the article.

Conflicts of Interest: The authors declare no conflict of interest.

Sample Availability: Sample of the compounds are available from the authors.

\section{References}

1. Saito, T.; Brown, R.H.; Hunt, M.A.; Pickel, D.L.; Pickel, J.M.; Messman, J.M.; Baker, F.S.; Keller, M.; Naskar, A.K. Turning renewable resources into value-added polymer: Development of lignin-based thermoplastic. Green Chem. 2012, 14, 3295-3303. [CrossRef]

2. Doherty, W.O.S.; Mousavioun, P.; Fellows, C.M. Value-adding to cellulosic ethanol: Lignin polymers. Ind. Crop. Prod. 2011, 33, 259-276. [CrossRef]

3. Stewart, D. Lignin as a base material for materials applications: Chemistry, application and economics. Ind. Crop. Prod. 2008, 27, 202-207. [CrossRef]

4. Xie, K.Y.; Wei, B.Q. Materials and Structures for Stretchable Energy Storage and Conversion Devices. Adv. Mater. 2017, $26,3592-3617$. [CrossRef]

5. Daffos, B.; Taberna, P.L.; Gogotsi, Y.; Simon, P. Recent Advances in Understanding the Capacitive Storage in Microporous Carbons. Fuel Cells 2010, 10, 819-824. [CrossRef]

6. Burke, A. R\&D considerations for the performance and application of electrochemical capacitors. Electrochim. Acta 2007, 53, 1083-1091.

7. Dubal, D.P.; Patil, S.V.; Gund, G.S.; Lokhande, C.D. Polyaniline-polypyrrole nanograined composite via electrostatic adsorption for high performance electrochemical supercapacitors. J. Alloys Compd. 2013, 552, 240-247. [CrossRef]

8. Li, S.M.; Wang, Y.S.; Yang, S.Y.; Liu, C.H.; Chang, K.H.; Tien, H.W.; Wen, N.T.; Ma, C.C.M.; Hu, C.C. Electrochemical deposition of nanostructured manganese oxide on hierarchically porous grapheme-carbon nanotube structure for ultrahigh-performance electrochemical capacitors. J. Power Sources 2013, 225, 347-355. [CrossRef]

9. Hou, Y.; Chen, L.Y.; Zhang, L.; Kang, J.; Fujita, T.; Jiang, J.; Chen, M. Ultrahigh capacitance of nanoporous metal enhanced conductive polymer pseudocapacitors. J. Power Sources 2013, 225, 304-310. [CrossRef]

10. Islam, M.S.; Fisher, C.A.J. Lithium and sodium battery cathode materials: Computational insights into voltage, diffusion and nanostructural properties. Chem. Soc. Rev. 2014, 43, 185-204. [CrossRef] [PubMed]

11. Wu, Z.S.; Parvez, K.; Feng, X.L. Graphene-based in-plane micro-supercapacitors with high power and energy densities. Nat. Commun. 2013, 4, 2487. [CrossRef] [PubMed]

12. Fu, F.B.; Yang, D.J.; Wang, H.; Qian, Y.; Yuan, F.; Zhong, J.; Qiu, X. Three-dimensional Porous Framework Lignin-Derived Carbon/ZnO Composite Fabricated by a Facile Electrostatic Self-Assembly Showing Good Stability for High-Performance Supercapacitors. ACS Sustain. Chem. Eng. 2019, 7, 16419-16427. [CrossRef]

13. Yang, S.H.; Liu, Y.Y.; Hao, Y.F.; Yang, X.P.; Goddard, W.A.; Zhang, X.L.; Cao, B.Q. Oxygen-Vacancy Abundant Ultrafine $\mathrm{Co}_{3} \mathrm{O}_{4} /$ Graphene Composites for High-Rate Supercapacitor Electrodes. Adv. Sci. 2018, 5, 1700659. [CrossRef]

14. Chen, Q.Y.; Chen, J.Z.; Zhou, Y.Y.; Song, C.; Tian, Q.H.; Xu, J.L.; Wong, C.P. Enhancing pseudocapacitive kinetics of nanostructured $\mathrm{MnO}_{2}$ through anchoring onto biomass-derived porous carbon. Appl. Surf. Sci. 2018, 440, 1027-1036. [CrossRef]

15. Zhang, Y.P.; Sun, X.W.; Pan, L.K.; Li, H.B.; Sun, Z.; Sun, C.P.; Tay, B.K. Carbon nanotube-ZnO nanocomposite electrodes for supercapacitors. Solid State Ion. 2009, 180, 1525-1528. [CrossRef]

16. Poonam Sharma, K.; Arora, A.; Tripathi, S.K. Review of supercapacitors: Materials and devices. J. Energy Storage 2019, 21, 801-825. [CrossRef]

17. Lach, J.; Wróbel, K.; Wróbel, J.; Czerwinski, A. Applications of Carbon in Rechargeable Electrochemical Power Sources: A Review. Energies 2021, 14, 2649. [CrossRef]

18. Majumder, M.; Choudhary, R.B.; Thakur, A.K. Hemispherical nitrogen-doped carbon spheres integrated with polyindole as high performance electrode material for supercapacitor applications. Carbon 2019, 142, 650-661. [CrossRef]

19. Thakur, A.K.; Choudhary, R.B.; Majumder, M.; Gupta, G. In-Situ Integration of Waste Coconut Shell Derived Activated Carbon/Polypyrrole/Rare Earth Metal Oxide $\left(\mathrm{Eu}_{2} \mathrm{O}_{3}\right)$ : A Novel Step Towards Ultrahigh Volumetric Capacitance. Electrochim. Acta 2017, 251, 532-545. [CrossRef]

20. Xu, S.W.; Zhao, Y.Q.; Xu, Y.X.; Chen, Q.H.; Zhang, G.Q.; Xu, Q.Q.; Zhao, D.D.; Zhang, X.; Xu, C.L. Heteroatom doped porous carbon sheets derived from protein-rich wheat gluten for supercapacitors: The synergistic effect of pore properties and heteroatom on the electrochemical performance in different electrolytes. J. Power Sources 2018, 401, 375-385. [CrossRef] 
21. Sevilla, M.; Ferrero, G.V.; Fuertes, A.B. Beyond KOH activation for the synthesis of superactivated carbons from hydrochar. Carbon 2017, 114, 50-58. [CrossRef]

22. Qiu, D.P.; Guo, N.N.; Gao, A.; Zheng, L.; Xu, W.J.; Li, M.; Wang, F.; Yang, R. Preparation of oxygen-enriched hierarchically porous carbon by $\mathrm{KMnO} 4$ one-pot oxidation and activation: Mechanism and capacitive energy storage. Electrochim. Acta 2019, 294, 398-405. [CrossRef]

23. Qiu, Z.P.; Wang, Y.S.; Bi, X.; Zhou, T.; Zhou, J.; Zhao, J.; Miao, Z.; Yi, W.; Fu, P.; Zhuo, S. Biochar-based carbons with hierarchical micro-meso-macro porosity for high rate and long cycle life supercapacitors. J. Power Sources 2018, 376, 82-90. [CrossRef]

24. Wu, Z.Y.; Fan, L.; Tao, Y.R.; Wang, W.; Wu, X.C.; Zhao, J.W. Pomelo Peel Derived Hierarchical Porous Carbon as Electrode Materials for High-Performance Supercapacitor. Chin. J. Inorg. Chem. 2018, 34, 1249-1260.

25. Li, Y.M.; Liu, X. Activated carbon/ZnO composites prepared using hydrochars as intermediate and their electrochemical performance in supercapacitor. Mater. Chem. Phys. 2014, 148, 380-386. [CrossRef]

26. Yun, S.I.; Kim, S.H.; Kim, D.W.; Kim, Y.A.; Kim, B.H. Facile preparation and capacitive properties of low-cost carbon nanofibers with $\mathrm{ZnO}$ derived from lignin and pitch as supercapacitor electrodes. Carbon 2019, 149, 637-645. [CrossRef]

27. Chen, F.; Zhou, W.J.; Yao, H.F.; Fan, P.; Yang, J.T.; Fei, Z.D.; Zhong, M.Q. Self-assembly of NiO nanoparticles in lignin-derived mesoporous carbons for supercapacitor applications. Green Chem. 2013, 15, 3057-3063. [CrossRef]

28. Lin, W.S.; Wang, H.; Yang, D.J.; Qiu, X.Q. Preparation of Lignin Carbon/Zinc Oxide Composite Material and Its Photocatalytic Performance. J. Chem. Eng. Chin. Univ. 2018, 32, 636-645.

29. Wang, H.; Yi, G.; Zu, X.; Qin, P.; Tan, M.; Luo, H. Photoelectric characteristics of the p-n junction between ZnOnanorods and polyaniline nanowires and their application as a UV photodetector. Mater. Lett. 2016, 162, 83-86. [CrossRef]

30. Demir, M.; Farghaly, A.A.; Decuir, M.J.; Collinson, M.M.; Gupta, R.B. Supercapacitance and Oxygen Reduction Characteristics of Sulfur Self-Doped Micro/Mesoporous Bio-Carbon Derived from Lignin. Mater. Chem. Phys. 2018, 216, 508-516. [CrossRef]

31. Ma, S.Y.; Bu, J.Y.; Duan, Y.; Hou, K.H. Deactivation of Bulk Ni-Mo Catalysts in Selective Hydrodeoxygenation of Sulfolane. J. Chem. Eng. Chin. Univ. 2017, 31, 863-869.

32. Tian, W.Q.; Gao, Q.M.; Tan, Y.L.; Yang, K.; Zhu, L.; Yang, C.; Zhang, H. Bio-inspired beehive-like hierarchical nanoporous carbon derived from bamboo-based industrial by-product as a high performance supercapacitor electrode material. J. Mater. Chem. A 2015, 3, 5656-5664. [CrossRef] 